\title{
Association between serum selenium level and type 2 diabetes mellitus: a non-linear dose-response meta-analysis of observational studies
}

\author{
Xin-liang Wang ${ }^{1}$, Tu-bao Yang ${ }^{1 *}$, Jie Wei ${ }^{12^{2 *}}$, Guang-hua Lei ${ }^{3}$ and Chao Zeng ${ }^{3}$
}

\begin{abstract}
Background: The association between serum selenium levels and type 2 diabetes mellitus (T2DM) is controversial. We performed a systematic review and non-linear dose-response meta-analysis of observational studies to investigate the association in the present study.

Methods: A comprehensive literature search was conducted using MEDLINE and EMBASE databases. A pooled odds ratio (OR) and related $95 \%$ confidence interval $(95 \% \mathrm{Cl})$ for T2DM between the highest and lowest serum selenium categories, and a non-linear dose-response relationship between selenium and T2DM were estimated.

Results: A total of five studies (of 13,460 participants) were identified as meeting the inclusion criteria. The pooled OR indicated that there was a significantly higher prevalence of T2DM in the highest category of blood selenium compared with the lowest $(\mathrm{OR}=1.63,95 \% \mathrm{Cl}: 1.04-2.56, P=0.033)$. Moreover, a significant non-linear dose-response relationship was observed between serum selenium levels and T2DM $(P<0.001)$. Serum selenium levels were positively associated with T2DM in populations with relatively low serum selenium levels $(<97.5 \mu \mathrm{g} / \mathrm{l})$ and those with high serum selenium levels $(>132.5 \mu \mathrm{g} / \mathrm{l})$.

Conclusions: The positive association between serum selenium levels and T2DM existed in populations with relatively low levels and high levels of serum selenium, indicating a likely U-shaped non-linear dose-response relationship between serum selenium and T2DM.
\end{abstract}

Keywords: Selenium, Type 2 diabetes mellitus, Observational studies, Non-linear dose-response meta-analysis

\section{Background}

Selenium is one of the most essential trace elements for human health. It functions as a redox center as part of the family of selenium-dependent glutathione peroxidases (GPx), transforming hydrogen peroxide and damaging lipid and phospholipid hydroperoxides into harmless products [1-3]. It is also a basic component of selenoproteins, which are a group of critically important enzymes [1]. In its protective role against oxidative stress, selenium has drawn increasing attention for preventing type 2 diabetes mellitus

\footnotetext{
*Correspondence: 1064960669@qq.com; weijie60112@163.com

${ }^{\dagger}$ Equal contributors

'Department of Epidemiology and Health Statistics, Xiangya School of Public Health, Central South University, Changsha 410008, Hunan Province, China Full list of author information is available at the end of the article
}

(T2DM), cardiovascular disease, cancer, and other chronic diseases [4-6]. Low selenium levels are thought to contribute to disease etiology, or may be a consequence of disease that aggravates the condition further [1].

T2DM is the most common form of diabetes, and is caused by a progressive insulin secretory defect against a background of insulin resistance [7]. Its relationship with oxidative stress may reflect the excess levels of reactive oxygen species in hyperglycemia. Oxidative stress has a huge impact on the etiology, pathogenesis, and complications of T2DM $[8,9]$. In view of the protective function of selenium against oxidative stress, selenium might be expected to play a protective role against T2DM. However, the relationship between selenium and T2DM is highly complex. The over-expression of GPx in islets may 
protect pancreatic $\beta$ cells from oxidative stress, stimulate pancreatic $\beta$ cell gene expression, and improve islet function [10-12]. Conversely, high selenium concentrations in the human body may interfere with insulin signaling, which is critical to the regulation of glucose levels and the prevention of diabetes $[13,14]$.

Many researchers have investigated the effects of blood selenium levels on T2DM, but the conclusions are controversial. Some studies report that blood selenium is negatively associated with T2DM [15-23], while others indicate a positive correlation [24-28]. Meanwhile, no significant association is documented by other reports [29-34]. Because of this complicated relationship between selenium and T2DM, we hypothesized that it might not be linear. Additionally, the selenium status and intake vary widely in different parts of the world [1], which might cause the inconsistencies observed in study outcomes.

A previous review article [5] suggested that there might be no standard or specific definition for serum or plasma selenium deficiencies. However, recommendations for dietary selenium intake are available, advising an average of $60 \mu \mathrm{g}$ per day for men and $53 \mu \mathrm{g}$ per day for women [35]. Several previous studies indicated that individuals with serum or plasma selenium concentrations of $122 \mu \mathrm{g} / \mathrm{L}$ or higher should not supplement with selenium [36, 37]. Conversely, those with serum or plasma selenium concentrations lower than $122 \mu \mathrm{g} / \mathrm{L}$ could benefit from increased levels (up to $130-150 \mu \mathrm{g} /$ L), which would reduce their mortality [38]. However, these findings were based on qualitative estimations, and the relationship between serum selenium levels and T2DM remains unclear.

Therefore, the objective of the present research was to comprehensively review the evidence on the association between serum selenium levels and T2DM by conducting a non-linear dose-response meta-analysis of observational studies.

\section{Methods}

\section{Search strategy}

This meta-analysis was conducted following Preferred Reporting Items for Systematic Reviews and Metaanalyses guidelines. MEDLINE and EMBASE databases were searched in September 2015 to identify relevant observational studies that investigated the relationship between blood selenium levels and T2DM. Search key words included "diabetes mellitus", "T2DM", "NIDDM", and "selenium". The specific search strategies are listed in Additional file 1: Appendix 1.

\section{Study selection}

Two researchers independently reviewed all citations and abstracts generated by the literature search. Qualified studies were subsequently examined for inclusion. Each researcher independently assessed the full texts in a blinded and standardized manner using a customized form to determine whether all inclusion criteria were met. Disagreements were resolved by discussion to reach a consensus.

Studies that met the following criteria were included: 1) observational comparative studies relating to the association between blood selenium levels and T2DM; 2) patients diagnosed with confirmed T2DM; 3 ) the exposure of interest was serum selenium levels, and at least three quantitative categories of selenium levels were classified; 4) the selenium level for each response category was provided or could be calculated; 5) the study reported numbers of cases and controls for each serum selenium category; and 6) full research articles. Exclusion criteria were: 1) patients with type 1 diabetes mellitus or gestational diabetes; 2) randomized controlled trials investigating the effect of selenium supplementation on T2DM; 3) review articles; 4) in vitro studies and animal experiments; and 5) short reports or meeting abstracts.

\section{Data extraction and quality assessment}

The following background information was extracted from the included studies: first author, publication year, country, study design, setting, study population, sample size, basic characteristics of participants (age, sex, and body mass index), and selenium classification. Data on the number of cases and participants in different selenium categories, and the odds ratios (ORs) of incidence/ prevalence of T2DM between the highest and the lowest selenium category were extracted for analysis.

The methodological quality of included studies was evaluated by the Newcastle-Ottawa Scale (NOS) [39], which was developed to assess the quality of nonrandomized studies based on three broad perspectives: selection of the study groups; comparability among different groups; and the ascertainment of either the exposure or outcome of interest. The total NOS score ranged from 0 to 9 based on the assessment items. Studies scoring higher than 6 were considered to have a high methodological quality.

\section{Statistical analysis}

The association between blood selenium levels and T2DM was evaluated by the pooled OR and related $95 \%$ confidence interval $(95 \% \mathrm{CI}$ ) for T2DM between the highest and lowest selenium categories. The heterogeneity of effect size across studies was tested by the Q statistic $\left(P<0.05\right.$ was considered heterogeneous) or $I^{2}$ statistic $\left(I^{2}>50 \%\right.$ was considered heterogeneous). The random effects model was used if significant heterogeneity was detected among studies; otherwise, the fixed effects model was applied. Sensitivity analysis was conducted to examine 
the influence of specific exclusion criteria on the overall effect size. Begg's tests [40] and funnel plots were performed to assess publication bias.

A two-stage random effects dose-response metaanalysis was conducted to investigate the potential non-linear dose-response relationship between blood selenium levels and T2DM [41]. First, a restricted cubic splines model with four knots at percentiles 5 , 35,65 , and $95 \%$ of the distribution was adopted using generalized least squares regression. Then, the restricted maximum likelihood method in a random effects meta-analysis was adopted to calculate the pooled study-specific estimates [42-44]. The median or mean selenium concentration for each category was assigned to each corresponding OR with $95 \%$ CI. When only the range of the selenium concentration was reported, the mid-point of the range was adopted to represent the category. When the category was open-ended, we assumed the open-ended interval length was the same as the adjacent interval $[45,46]$.

Statistical analyses were performed using STATA version 11.0 (StataCorp LP, College Station, TX). $P<0.05$ was considered to be statistically significant.

\section{Statistical analysis}

The association between blood selenium level and T2DM were evaluated by a pooled OR and related $95 \%$ confidence interval $(95 \% \mathrm{CI})$ for T2DM between the highest and the lowest selenium category. The heterogeneity of effect size across studies was tested by Q statistic $\left(\mathrm{p}<0.05\right.$ was considered heterogeneous) or $\mathrm{I}^{2}$ statistic $\left(\mathrm{I}^{2}>50 \%\right.$ was considered heterogeneous). If there was a significant heterogeneity among studies, the random-effects model was used; otherwise, the fixedeffects model was applied. A sensitivity analysis was conducted to examine the influence of specific exclusion criteria on the overall effect sizes. Begg's tests [40] and funnel plot was performed to assess the publication bias.

For the potential non-linear dose-response relationship between blood selenium level and T2DM, a 2-stage, random effects, dose-response meta-analysis was conducted [41]. Firstly, restricted cubic splines model with four knots at percentiles 5, 35, 65 and $95 \%$ of the distribution was adopted by using generalized least squares regression. Then the restricted maximum likelihood method in a random-effects meta-analysis was adopted to calculate the pooled study-specific estimates [42-44]. The median or mean selenium concentration for each category was assigned to each corresponding ORs with $95 \%$ CI. When only range of selenium concentration was reported, the mid-point of the range was adopted for representing the category. When the category was open-ended, we assumed the open-ended interval length to be the same as the adjacent interval $[45,46]$.
Statistical analyses were performed using STATA version 11.0 (StataCorp LP, College Station, Texas). $P<0.05$ was considered to be statistically significant.

\section{Results}

\section{Literature search}

Figure 1 shows the selection process of the observational studies included in this study. A total of 1404 records were selected following the search strategies. After removing duplicate records, 991 abstracts and titles were initially identified. Of these, 948 records were excluded because they did not meet inclusion criteria, and the remaining 43 full-text studies were evaluated for eligibility. Eventually, a total of five studies were included in this research.

\section{Study characteristics}

The characteristics of the included studies and subjects are shown in Table 1. A total of 13,460 participants were included within the five studies [25, 27, 28, 32, 47]. The studies were published from 1998 to 2015; two were conducted in the United States [25, 27], two in Sweden $[32,47]$, and one in Italy [28]. Three studies were longitudinal studies $[28,32,47]$, but two of these were considered to be cross-sectional because the data were extracted from baseline [28, 47]. The remaining two studies were also cross-sectional [25, 27]. The community population was targeted in all included studies, and

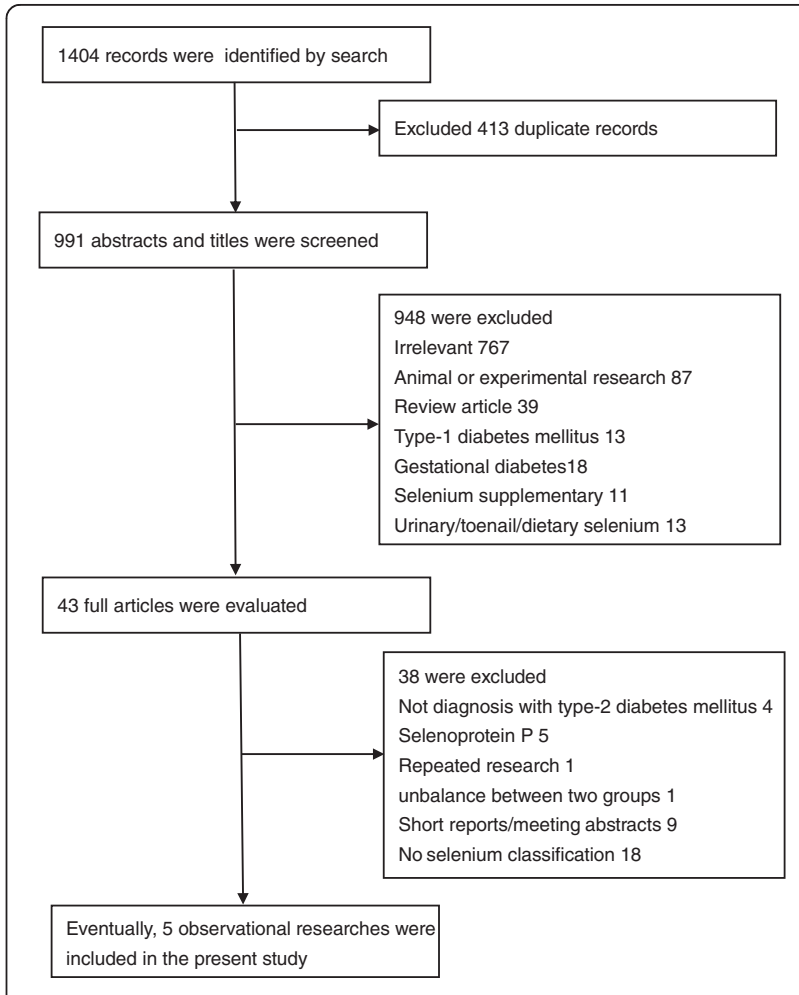

Fig. 1 Flow chart of the selection process of the included studies 
Table 1 Characteristics of studies included in the meta-analysis

\begin{tabular}{|c|c|c|c|c|c|c|c|c|}
\hline $\begin{array}{l}\text { First author, } \\
\text { year and country }\end{array}$ & Study design & Setting, study population & $\begin{array}{l}\text { Sample } \\
\text { size (n) }\end{array}$ & $\begin{array}{l}\text { Age, } \\
\text { mean }\end{array}$ & $\begin{array}{l}\text { Male } \\
(\%)\end{array}$ & BMI $\left(\mathrm{kg} / \mathrm{m}^{2}\right)$, mean & $\begin{array}{l}\text { Selenium } \\
\text { classification (range) }\end{array}$ & Definition of T2DM \\
\hline $\begin{array}{l}\text { Alehagen 2015, } \\
\text { Sweden }\end{array}$ & $\begin{array}{l}\text { Longitudinal } \\
\text { study (data } \\
\text { were extracted } \\
\text { from baseline) }\end{array}$ & $\begin{array}{l}\text { Community, rural municipality } \\
\text { of inhabitants in the south- } \\
\text { east of Sweden. }\end{array}$ & 668 & 77.7 & 47.8 & NR & $\begin{array}{l}\text { Quartiles: }<57.2 \\
57.2-67.1,67.1-76.1 \\
>76.1 \mu \mathrm{g} / \mathrm{l}\end{array}$ & NR \\
\hline $\begin{array}{l}\text { Bleys 2007, } \\
\text { USA }\end{array}$ & $\begin{array}{l}\text { Cross-sectional } \\
\text { study }\end{array}$ & $\begin{array}{l}\text { Community, NHANES III } \\
\text { participants }\end{array}$ & 8876 & 45.2 & 49.1 & 26.9 & $\begin{array}{l}\text { Quintiles: }<111.62 \\
111.62-120.17 \\
120.18-128.25 \\
128.26-137.65 \\
>137.65 \mu \mathrm{g} / \mathrm{l}\end{array}$ & $\begin{array}{l}\text { Defined as a fasting plasma glucose } \geq 126 \mathrm{mg} / \mathrm{dl} \text {, a self-report } \\
\text { of a physician diagnosis of diabetes, or current use of insulin or } \\
\text { oral hypoglycemic medication }\end{array}$ \\
\hline $\begin{array}{l}\text { Laclaustra 2009, } \\
\text { USA }\end{array}$ & $\begin{array}{l}\text { Cross-sectional } \\
\text { study }\end{array}$ & $\begin{array}{l}\text { Community, civilian non- } \\
\text { institutionalized U.S. popula- } \\
\text { tion from NHANES 2003-2004 }\end{array}$ & 890 & 54.4 & 47.0 & 28.8 & $\begin{array}{l}\text { Quartiles: }<124, \\
124-133,134-146, \\
>146 \mu \mathrm{\mu g} / \mathrm{l}\end{array}$ & $\begin{array}{l}\text { Defined as the presence of either a self-report of current use of } \\
\text { hypoglycemic agents or insulin or fasting plasma glucose } \geq \\
126 \mathrm{mg} / \mathrm{dL} \text {. }\end{array}$ \\
\hline $\begin{array}{l}\text { Stranges 2011, } \\
\text { Italy }\end{array}$ & $\begin{array}{l}\text { Longitudinal } \\
\text { study (data } \\
\text { were extracted } \\
\text { from baseline) }\end{array}$ & $\begin{array}{l}\text { Community, male workforce } \\
\text { of the Olivetti factories in } \\
\text { Pozzuoli (Naples) and } \\
\text { Marcianise (Caserta), Southern } \\
\text { Italy. }\end{array}$ & 445 & 50.9 & 100 & 26.8 & $\begin{array}{l}\text { Tertiles: <69.7, } \\
69.7-82.6,>82.6 \mu \mathrm{g} / \mathrm{l}\end{array}$ & $\begin{array}{l}\text { Defined as a fasting blood glucose level } \geq 126 \mathrm{mg} / \mathrm{dL} \\
\text { or anti-diabetic therapy. }\end{array}$ \\
\hline $\begin{array}{l}\text { Gao 2014, } \\
\text { Sweden }\end{array}$ & $\begin{array}{l}\text { Longitudinal } \\
\text { Study }\end{array}$ & $\begin{array}{l}\text { Community, all 50-year-old } \\
\text { men living in Uppsala County, } \\
\text { Sweden. }\end{array}$ & 1925 & 49.7 & 100 & 25.0 & $\begin{array}{l}\text { Tertiles: 61.4, 75.1, } \\
91.1 \mu \mathrm{g} / \mathrm{l}^{\mathrm{a}}\end{array}$ & $\begin{array}{l}\text { Defined by elevated fasting glucose levels and/or use } \\
\text { of anti-diabetic medicine. Elevated glucose levels were } \\
\text { assessed as fasting blood glucose } \geq 6.1 \mathrm{mmol} / \mathrm{l} \text { at the age } \\
60 \text { years' examination (equals } \geq 7.0 \mathrm{mmol} / \mathrm{l} \text { of plasma glucose) } \\
\text { and fasting plasma glucose } \geq 7.0 \mathrm{mmol} / \mathrm{l} \text { at age } 70 \text { years and } \\
\text { age } 77 \text { years }\end{array}$ \\
\hline
\end{tabular}


Table 2 Methodological quality assessment according to Newcastle-Ottawa Scale (NOS)

\begin{tabular}{|c|c|c|c|c|c|c|c|c|c|}
\hline \multirow[t]{2}{*}{ Study } & \multicolumn{4}{|l|}{ Selection } & \multirow{2}{*}{$\begin{array}{l}\text { Comparability } \\
\text { Comparability of } \\
\text { cases and controls } \\
\text { (worth } 2 \text { points) }\end{array}$} & \multicolumn{3}{|c|}{ Exposure/outcome } & \multirow{2}{*}{$\begin{array}{l}\text { Total } \\
\text { score }\end{array}$} \\
\hline & $\begin{array}{l}\text { Adequate } \\
\text { definition } \\
\text { of case/ } \\
\text { exposed } \\
\text { cohort }\end{array}$ & $\begin{array}{l}\text { Representativeness } \\
\text { of the cases/ } \\
\text { exposed } \\
\text { cohort }\end{array}$ & $\begin{array}{l}\text { Selection } \\
\text { of Controls }\end{array}$ & $\begin{array}{l}\text { Definition } \\
\text { of Controls }\end{array}$ & & $\begin{array}{l}\text { Ascertainment } \\
\text { of exposure/ } \\
\text { outcome }\end{array}$ & $\begin{array}{l}\text { Same method of } \\
\text { ascertainment for } \\
\text { cases and controls/ } \\
\text { long enough for } \\
\text { outcomes to occur }\end{array}$ & $\begin{array}{l}\text { Non- } \\
\text { Response } \\
\text { Rate }\end{array}$ & \\
\hline $\begin{array}{l}\text { Alehagen } \\
2015\end{array}$ & 1 & 1 & 1 & 1 & 0 & 1 & 1 & 1 & 7 \\
\hline Bleys 2007 & 1 & 1 & 1 & 1 & 2 & 1 & 1 & 1 & 9 \\
\hline Gao 2014 & 1 & 1 & 1 & 1 & 2 & 1 & 1 & 1 & 9 \\
\hline $\begin{array}{l}\text { Laclaustra } \\
2009\end{array}$ & 1 & 1 & 1 & 1 & 2 & 1 & 1 & 1 & 9 \\
\hline $\begin{array}{l}\text { Stranges } \\
2011\end{array}$ & 1 & 1 & 1 & 1 & 0 & 1 & 1 & 1 & 7 \\
\hline
\end{tabular}

the sample size varied from 445 to 8876 . The methodological quality, based on NOS, is reported in Table 2. All studies were evaluated with a high methodological quality: three studies scored 9 and two studies scored 7.

\section{OR for T2DM between different serum selenium categories}

The pooled data analysis indicated that there was a significantly higher prevalence of T2DM in the highest category of blood selenium compared with the lowest $(\mathrm{OR}=1.63,95 \% \mathrm{CI}: 1.04-2.56, P=0.033$, Fig. 2). Unfortunately, significant heterogeneity was observed among different studies $\left(P=0.009, I^{2}=70.3 \%\right)$. No evidence of publication bias was observed according to the Begg rank-correlation test among the included studies $(P=$ 0.221). The Begg's funnel plot is shown in Additional file 1: Appendix 2.

Because of the substantial degree of heterogeneity among studies, a qualitative analysis was adopted. As shown in Fig. 3, a significant association was observed between high serum selenium concentrations and increased prevalence of T2DM in studies including participants with relatively high selenium concentrations $[25,27]$. Studies conducted in participants with relatively lower selenium concentrations did not show a significant association between serum selenium concentration and T2DM [28, 32, 47]. We also performed a sensitivity analysis by excluding one study [27] that was an outlier; the outcome suggested a similar positive association between T2DM and serum selenium $(\mathrm{OR}=1.32$, $95 \%$ CI: $1.12-1.54, P=0.001)$ but with a significantly decreased level of heterogeneity $\left(P=0.495, I^{2}=0 \%\right)$.

\section{Non-linear dose-response relationship between blood selenium and T2DM}

A significant non-linear dose-response relationship between blood selenium levels and T2DM was found $(P<$ 0.001 for nonlinearity; Fig. 4). The reference selenium level was $52.5 \mu \mathrm{g} / \mathrm{l}$. When serum selenium concentrations exceeded $132.5 \mu \mathrm{g} / \mathrm{l}$, they were strongly positively associated with increased prevalence of T2DM. There was also

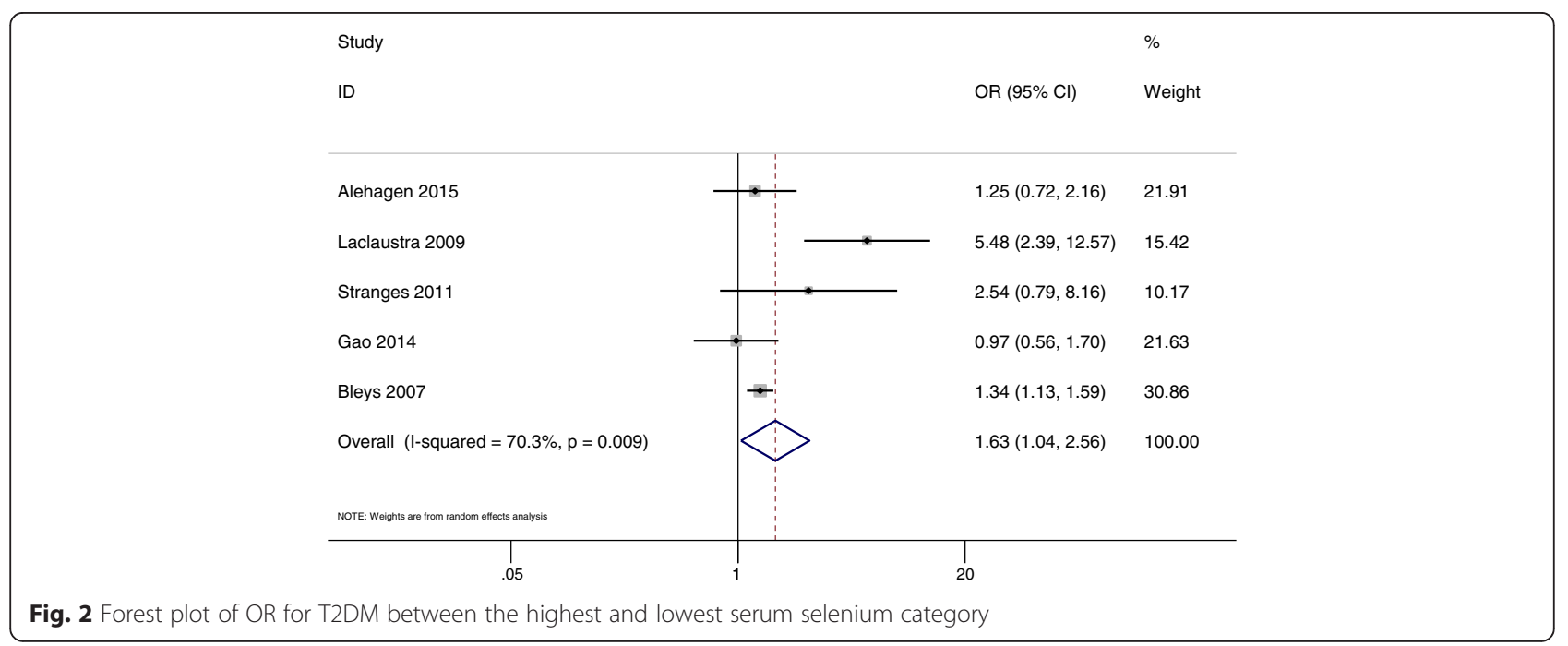




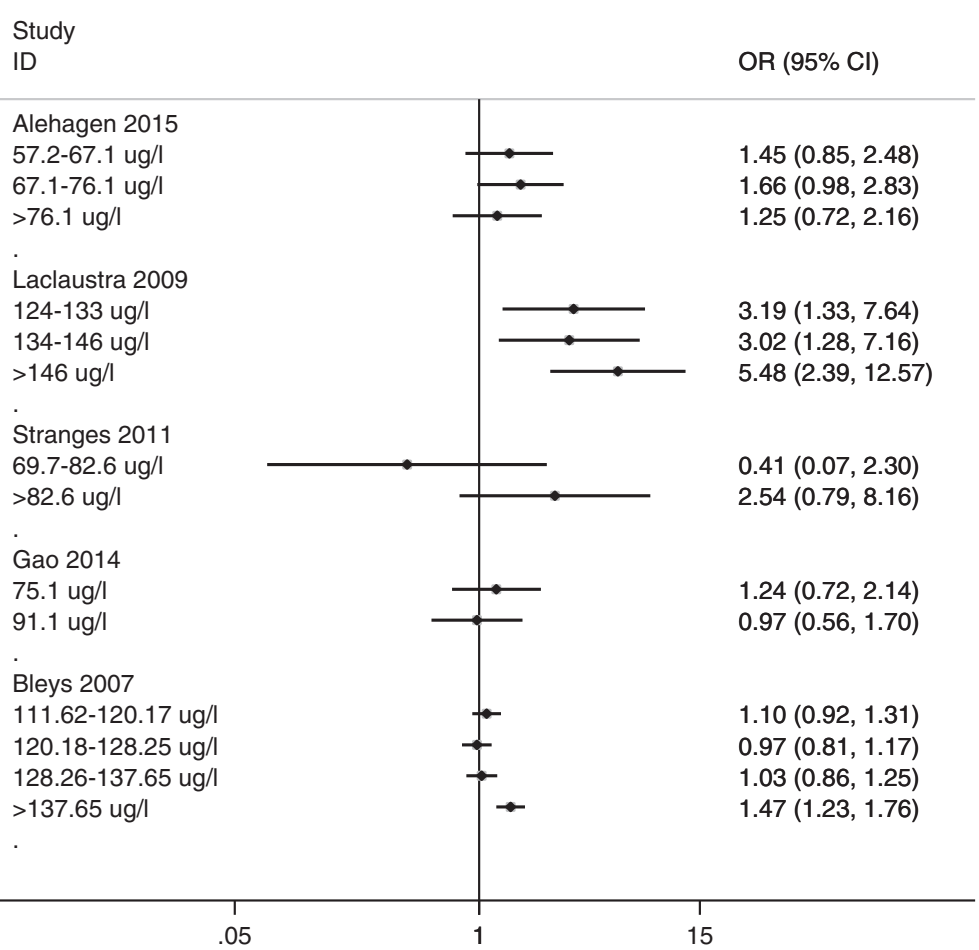

Fig. 3 Forest plot of OR for T2DM between different serum selenium categories and the lowest category (reference) in individual study

a moderately positive association between serum selenium and T2DM when individuals had relatively low levels of serum selenium $(<97.5 \mu \mathrm{g} / \mathrm{l})$. However, the positive association began to disappear with a flattening of the curve at the middle level $(97.5-132.5 \mu \mathrm{g} / \mathrm{l})$ of serum selenium.

\section{Discussion}

To the best of our knowledge, this is the first systematic review and dose-response meta-analysis examining the association between serum selenium levels and T2DM based on previous observational studies. We found a

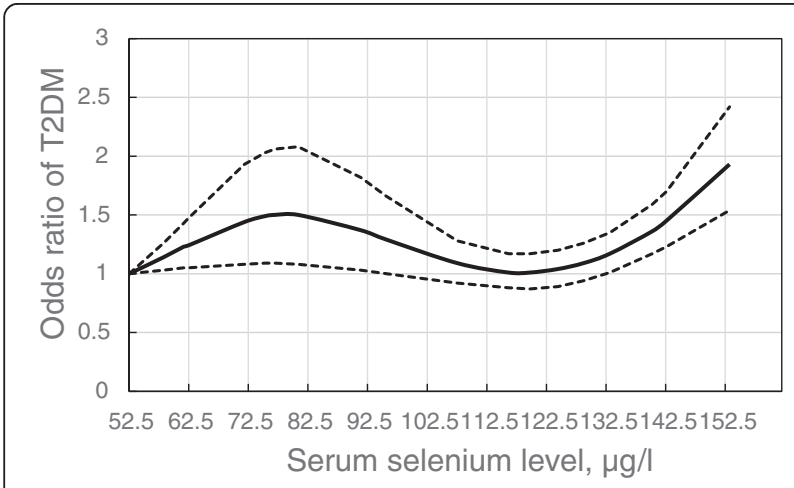

Fig. 4 Nonlinear dose-response relationship between selenium and T2DM. The middle line represents the odds ratio of T2DM compared with reference $(53.5 \mathrm{ug} / \mathrm{l})$, and the upper and lower lines represent $95 \% \mathrm{Cl}$ of the odds ratio significantly higher prevalence of T2DM in the highest category of blood selenium compared with the lowest, and serum selenium levels were positively associated with T2DM in populations with relatively low $(<97.5 \mu \mathrm{g} /$ 1) or high serum selenium levels $(>132.50 \mu \mathrm{g} / \mathrm{l})$.

Previous evidence about the relationship between selenium and T2DM is conflicting. Some studies claim that patients with T2DM have significantly lower selenium concentrations compared with healthy subjects [15-23]. Antioxidants in non-diabetic individuals can mitigate free radical-mediated oxidative stress, but in the chronic hyperglycemia state, increased free radical production may lead to the overconsumption of chain-breaking antioxidants, elevated lipid peroxidation, and enhanced oxidative stress [22]. Selenium is believed to be one of the most important antioxidant nutrients in the human body, and selenoproteins have a protective effect against oxidative stress and inflammation $[5,8]$. However, the lower selenium status measured in T2DM populations of some case-control studies might be caused by the disease and its association with inflammation. Other previous studies have suggested that the inflammatory response decreases the expression of selenoprotein $\mathrm{P}$ and reduces plasma selenium concentrations [48, 49].

Conversely, some studies report that patients with T2DM have higher selenium concentrations compared with healthy subjects, and that blood selenium levels positively correlate with T2DM [24-28]. The over- 
expression of GPx1 in transgenic mice was found to lead to the development of insulin resistance, hyperglycemia, hyperinsulinemia, and obesity. After knocking out GPx1, both insulin-induced glucose uptake and insulin sensitivity were improved [50-52]. This was explained by GPx1 removing hydrogen peroxide, a second messenger in the insulin signaling cascade, and insulin binding to its receptor [14]. The same correlation was also observed between increased erythrocyte GPx1 activity and mild insulin resistance in pregnant women [53]. Another selenoprotein, SeP, was also shown to be related to insulin resistance by aggravating insulin resistance through impairing insulin signaling [54]. Studies have revealed a significantly positive association between SeP and fasting plasma glucose in Japanese and Korean populations [54, 55]. Moreover, in an earlier study, we found a significant positive correlation between dietary selenium intake and the prevalence of diabetes [56].

Previous review articles have suggested that the association between selenium and T2DM is U-shaped, such that selenoprotein levels both below and above the physiological range are possible risk factors for T2DM $[5,8,12]$. This estimation is consistent with our nonlinear dose-response analysis. We observed a moderately positive association between selenium and T2DM in individuals with relatively low levels of serum selenium $(<100 \mu \mathrm{g} / \mathrm{l})$, a non-significant association between selenium and T2DM in individuals with middle levels of serum selenium $(100-130 \mu \mathrm{g} / \mathrm{l})$, and a strongly positive association in individuals with relatively high levels of serum selenium $(>130 \mu \mathrm{g} / \mathrm{l})$. Stranges et al. [37] concluded that selenium supplementation does not prevent T2DM, but may instead increase the disease risk in populations with a median serum selenium level of $136 \mu \mathrm{g} / \mathrm{l}$. Another study suggested that both high and low expression levels of GPx1 and other related selenoproteins are harmful because of their effects on insulin resistance and hyperglycemia [57].

The present study has several strengths. It is the first meta-analysis to perform a systematic and quantitative analysis of the association between serum/plasma selenium levels and T2DM. Several review articles [5, 8, 12] have attempted to examine this relationship, but none performed a quantitative analysis. Second, this study showed a specific non-linear dose-response relationship between serum selenium levels and T2DM. However, the limitations of the present study should also be acknowledged. The number of studies included in the analysis was very limited. Second, the shortage of prospective cohort studies could explain the causal relationship between selenium and T2DM. Therefore, future prospective cohort studies are needed to further explore this relationship. Finally, because glucose levels vary greatly in patients with
T2DM, direct correlations of selenium levels with glucose levels would provide us with relevant information. Unfortunately, only two studies [27, 32] have reported these data. Additionally, the search strategy and included studies required for these analyses would differ from those of the present meta-analysis. Thus, this would best be examined as part of a future study.

\section{Conclusion}

In conclusion, we detected a positive association between serum selenium levels and T2DM in populations with relatively low and high serum levels of selenium, revealing a U-shaped non-linear dose-response relationship between serum selenium and T2DM.

\section{Additional file}

Additional file 1: Appendix 1. Search strategies. Appendix 2.

Beggs'funnel plot. (DOCX $18 \mathrm{~kb}$ )

\section{Competing interests}

The authors declare that they have no competing interests.

\section{Authors' contributions}

XW and JW design the study, analyses data and drafted the manuscript. JW, TY, GL, and CZ conceived of the study, and participated in study design and coordination, and helped to draft the manuscript. JW and TY revised the manuscript. All authors read and approved the final manuscript.

\section{Funding sources}

This work was supported by the Fundamental Research Funds for the Central Universities of Central South University (2014zzts070), the Hunan Provincial Innovation Foundation for Postgraduate (CX2014B096).

\section{Author details}

${ }^{1}$ Department of Epidemiology and Health Statistics, Xiangya School of Public Health, Central South University, Changsha 410008, Hunan Province, China.

${ }^{2}$ Health Management Center, Xiangya Hospital, Central South University, Changsha 410008, Hunan Province, China. ${ }^{3}$ Department of Orthopaedics, Xiangya Hospital, Central South University, Changsha 410008, Hunan Province, China.

Received: 5 January 2016 Accepted: 26 April 2016

Published online: 04 May 2016

\section{References}

1. Rayman MP. The importance of selenium to human health. Lancet. 2000; 356(9225):233-41.

2. Allan CB, Lacourciere GM, Stadtman TC. Responsiveness of selenoproteins to dietary selenium. Annu Rev Nutr. 1999;19:1-16.

3. Diplock AT. Antioxidants and disease prevention. Mol Aspects Med. 1994: 15(4):293-376

4. Neve J. Selenium as a risk factor for cardiovascular diseases. J Cardiovasc Risk. 1996;3(1):42-7.

5. Rayman MP. Selenium and human health. Lancet. 2012;379(9822):1256-68

6. Steinbrenner $\mathrm{H}$, Sies $\mathrm{H}$. Protection against reactive oxygen species by selenoproteins. Biochim Biophys Acta. 2009;1790(11):1478-85.

7. American Diabetes Association. Standards of medical care in diabetes_2014. Diabetes Care. 2014;37(1):S14-80.

8. Rayman MP, Stranges S. Epidemiology of selenium and type 2 diabetes: can we make sense of it? Free Radic Biol Med. 2013;65:1557-64.

9. Robertson RP, Harmon JS. Pancreatic islet beta-cell and oxidative stress: the importance of glutathione peroxidase. Febs Lett. 2007;581(19):3743-8. 
10. Campbell SC, Aldibbiat A, Marriott CE, Landy C, Ali T, Ferris WF, Butler CS, Shaw JA, Macfarlane WM. Selenium stimulates pancreatic beta-cell gene expression and enhances islet function. Febs Lett. 2008;582(15):2333-7.

11. Monnier L, Mas E, Ginet C, Michel F, Villon L, Cristol JP, Colette C. Activation of oxidative stress by acute glucose fluctuations compared with sustained chronic hyperglycemia in patients with type 2 diabetes. JAMA. 2006;295(14):1681-7.

12. Rocourt $\mathrm{CR}$, Cheng $\mathrm{WH}$. Selenium supranutrition: are the potential benefits of chemoprevention outweighed by the promotion of diabetes and insulin resistance? Nutr. 2013;5(4):1349-65.

13. Goldstein BJ, Mahadev K, Wu X. Redox paradox: insulin action is facilitated by insulin-stimulated reactive oxygen species with multiple potential signaling targets. Diabetes. 2005;54(2):311-21.

14. Steinbrenner $H$, Speckmann B, Pinto A, Sies H. High selenium intake and increased diabetes risk: experimental evidence for interplay between selenium and carbohydrate metabolism. J Clin Biochem Nutr. 2011;48(1):40-5.

15. Joshi U, Raut P, Agrawal S, Patra P, Maheshwari B, Apurb M, TC D. Evaluation of serum selenium level in patients with uncomplicated diabetes mellitus, Raipur, India. J Clin Diagn Res. 2011;5:70-3.

16. Kljai K, Runje R. Selenium and glycogen levels in diabetic patients. Biol Trace Elem Res. 2001;83(3):223-9.

17. Kornhauser C, Garcia-Ramirez JR, Wrobel K, Perez-Luque EL, Garay-Sevilla ME, Wrobel K. Serum selenium and glutathione peroxidase concentrations in type 2 diabetes mellitus patients. Prim Care Diabetes. 2008;2(2):81-5.

18. Navarro-Alarcon M, Lopez-G DLSH, Perez-Valero V, Lopez-Martinez C. Serum and urine selenium concentrations as indicators of body status in patients with diabetes mellitus. Sci Total Environ. 1999;228(1):79-85.

19. Salem M, Kholoussi S, Kholoussi N, Fawzy R. Malondialdehyde and trace element levels in patients with type 2 diabetes mellitus. Arch hell med. 2011;28(1):83-8.

20. Serdar MA, Bakir F, Haşimi A, Çelik T, Akin O, Kenar L, Aykut O, Yildirimkaya $M$. Trace and toxic element patterns in nonsmoker patients with noninsulindependent diabetes mellitus, impaired glucose tolerance, and fasting glucose. Int j diabetes dev ctries. 2009;29(1):35.

21. Thomas B, Ramesh A, Suresh S, Prasad BR. A comparative evaluation of antioxidant enzymes and selenium in the serum of periodontitis patients with diabetes mellitus type 2. Contemp clin dent. 2013;4(2):176.

22. Whiting $\mathrm{PH}$, Kalansooriya A, Holbrook I, Haddad F, Jennings PE. The relationship between chronic glycaemic control and oxidative stress in type 2 diabetes mellitus. Br J Biomed Sci. 2008:65(2):71-4.

23. Zhao C, Wang H, Zhang J, Feng L. [Correlations of trace elements, glucose and body compositions in type 2 diabetics]. Wei Sheng Yan Jiu. 2008;37(5): 600-1. 605.

24. Agte $\mathrm{W}$, Tarwadi KV. Combination of diabetes and cataract worsens the oxidative stress and micronutrient status in Indians. Nutrition. 2008; 24(7-8):617-24

25. Bleys J, Navas-Acien A, Guallar E. Serum selenium and diabetes in U.S. adults. Diabetes Care. 2007;30(4):829-34

26. Flores CR, Puga MP, Wrobel K, Garay SM, Wrobel K. Trace elements status in diabetes mellitus type 2: possible role of the interaction between molybdenum and copper in the progress of typical complications. Diabetes Res Clin Pract. 2011;91(3):333-41.

27. Laclaustra M, Navas-Acien A, Stranges S, Ordovas JM, Guallar E. Serum selenium concentrations and diabetes in U.S. Adults: national health and nutrition examination survey (NHANES) 2003-2004. Environ Health Perspect. 2009;117(9):1409-13.

28. Stranges S, Galletti F, Farinaro E, D'Elia L, Russo O, lacone R, Capasso C, Carginale V, De Luca V, Della VE et al. Associations of selenium status with cardiometabolic risk factors: an 8-year follow-up analysis of the Olivetti heart study. Atherosclerosis. 2011;217(1):274-8.

29. Coudray C, Roussel AM, Mainard F, Arnaud J, Favier A. Lipid peroxidation level and antioxidant micronutrient status in a pre-aging population; correlation with chronic disease prevalence in a French epidemiological study (Nantes, France). J Am Coll Nutr. 1997;16(6):584-91.

30. Ekmekcioglu C, Prohaska C, Pomazal K, Steffan I, Schernthaner G, Marktl W. Concentrations of seven trace elements in different hematological matrices in patients with type 2 diabetes as compared to healthy controls. Biol Trace Elem Res. 2001;79(3):205-19.

31. Forte G, Bocca B, Peruzzu A, Tolu F, Asara Y, Farace C, Oggiano R, Madeddu R. Blood metals concentration in type 1 and type 2 diabetics. Biol Trace Elem Res. 2013;156(1-3):79-90.
32. Gao H, Hagg S, Sjogren P, Lambert PC, Ingelsson E, van Dam RM. Serum selenium in relation to measures of glucose metabolism and incidence of type 2 diabetes in an older Swedish population. Diabet Med. 2014;31(7):787-93.

33. Hughes K, Choo M, Kuperan P, Ong CN, Aw TC. Cardiovascular risk factors in non-insulin-dependent diabetics compared to non-diabetic controls: a population-based survey among Asians in Singapore. Atherosclerosis. 1998;136(1):25-31.

34. Yerlikaya FH, Toker A, Aribas A. Serum trace elements in obese women with or without diabetes. Indian J Med Res. 2013;137(2):339-45.

35. Rayman MP, Infante HG, Sargent M. Food-chain selenium and human health: spotlight on speciation. Br J Nutr. 2008;100(2):238-53.

36. Clark LC, Combs GJ, Turnbull BW, Slate EH, Chalker DK, Chow J, Davis LS, Glover RA, Graham GF, Gross EG et al. Effects of selenium supplementation for cancer prevention in patients with carcinoma of the skin. A randomized controlled trial. Nutritional Prevention of Cancer Study Group. JAMA. 1996; 276(24):1957-63.

37. Stranges S, Marshall JR, Natarajan R, Donahue RP, Trevisan M, Combs GF, Cappuccio FP, Ceriello A, Reid ME. Effects of long-term selenium supplementation on the incidence of type 2 diabetes: a randomized trial. Ann Intern Med. 2007;147(4):217-23.

38. Bleys J, Navas-Acien A, Guallar E. Serum selenium levels and all-cause, cancer, and cardiovascular mortality among US adults. Arch Intern Med. 2008;168(4):404-10.

39. Wells GA, Shea B, O'Connell D, Peterson J, Welch V, Losos M, Tugwell P. The Newcastle-Ottawa Scale (NOS) for assessing the quality of nonrandomised studies in meta-analyses. 2000. Available at: http://www.ohri.ca/programs/ clinical_epidemiology/oxford.asp.

40. Begg CB, Mazumdar M. Operating characteristics of a rank correlation test for publication bias. Biometrics. 1994;50(4):1088-101.

41. Orsini N, Li R, Wolk A, Khudyakov P, Spiegelman D. Meta-analysis for linear and nonlinear dose-response relations: examples, an evaluation of approximations, and software. Am J Epidemiol. 2012;175(1):66-73.

42. Bo Y, Lu Y, Zhao Y, Zhao E, Yuan L, Lu W, Cui L, Lu Q: Association between dietary vitamin C intake and risk of esophageal cancer: A dose-response meta-analysis. Int J Cancer. 2016;138(8):1843-50.

43. Gao D, Ning N, Wang C, Wang Y, Li Q, Meng Z, Liu Y, Li Q. Dairy products consumption and risk of type 2 diabetes: systematic review and dose-response meta-analysis. PLoS One. 2013;8(9), e73965.

44. Larsson SC, Orsini N, Wolk A. Vitamin B6 and risk of colorectal cancer: a meta-analysis of prospective studies. JAMA. 2010;303(11):1077-83.

45. Aune D, Saugstad OD, Henriksen T, Tonstad S. Maternal body mass index and the risk of fetal death, stillbirth, and infant death: a systematic review and meta-analysis. JAMA. 2014;311(15):1536-46.

46. Xu C, Liu T, Kuang $X$, Zhang $Y$, Weng H, Zhang C. How to estimate the missing data and transform the effect measure in dose-response metaanalysis. Chin J Evid-based Med. 2015;15(8):984-7.

47. Alehagen U, Johansson P, Bjornstedt M, Rosen A, Post C, Aaseth J. Relatively high mortality risk in elderly Swedish subjects with low selenium status. Eur J Clin Nutr. 2015.

48. Hesse-Bahr K, Dreher I, Kohrle J. The influence of the cytokines I-1 beta and INFgamma on the expression of selenoproteins in the human hepatocarcinoma cell line HepG2. Biofactors. 2000;11(1-2):83-5.

49. Nichol C, Herdman J, Sattar N, O'Dwyer PJ, St JOD, Littlejohn D, Fell G. Changes in the concentrations of plasma selenium and selenoproteins after minor elective surgery: further evidence for a negative acute phase response? Clin Chem. 1998:44(8 Pt 1):1764-6.

50. Loh K, Deng H, Fukushima A, Cai X, Boivin B, Galic S, Bruce C, Shields BJ, Skiba B, Ooms LM et al. Reactive oxygen species enhance insulin sensitivity. Cell Metab. 2009;10(4):260-72.

51. McClung JP, Roneker CA, Mu W, Lisk DJ, Langlais P, Liu F, Lei XG. Development of insulin resistance and obesity in mice overexpressing cellular glutathione peroxidase. Proc Natl Acad Sci U S A. 2004;101(24):8852-7.

52. Wang XD, Vatamaniuk MZ, Wang SK, Roneker CA, Simmons RA, Lei XG. Molecula mechanisms for hyperinsulinaemia induced by overproduction of seleniumdependent glutathione peroxidase-1 in mice. Diabetologia. 2008;51(8):1515-24

53. Chen X, Scholl TO, Leskiw MJ, Donaldson MR, Stein TP. Association of glutathione peroxidase activity with insulin resistance and dietary fat intake during normal pregnancy. J Clin Endocrinol Metab. 2003;88(12):5963-8.

54. Misu H, Takamura T, Takayama H, Hayashi H, Matsuzawa-Nagata N, Kurita S, Ishikura K, Ando H, Takeshita Y, Ota T et al. A liver-derived secretory protein, selenoprotein P, causes insulin resistance. Cell Metab. 2010;12(5):483-95. 
55. Yang SJ, Hwang SY, Choi HY, Yoo HJ, Seo JA, Kim SG, Kim NH, Baik SH, Choi DS, Choi KM. Serum selenoprotein P levels in patients with type 2 diabetes and prediabetes: implications for insulin resistance, inflammation, and atherosclerosis. J Clin Endocrinol Metab. 2011;96(8):E1325-9.

56. Wei J, Zeng C, Gong QY, Yang HB, Li XX, Lei GH, Yang TB. The association between dietary selenium intake and diabetes: a cross-sectional study among middle-aged and older adults. Nutr J. 2015;14:18.

57. Labunskyy VM, Lee BC, Handy DE, Loscalzo J, Hatfield DL, Gladyshev VN. Both maximal expression of selenoproteins and selenoprotein deficiency can promote development of type 2 diabetes-like phenotype in mice. Antioxid Redox Signal. 2011;14(12):2327-36.

Submit your next manuscript to BioMed Central and we will help you at every step:

- We accept pre-submission inquiries

- Our selector tool helps you to find the most relevant journal

- We provide round the clock customer support

- Convenient online submission

- Thorough peer review

- Inclusion in PubMed and all major indexing services

- Maximum visibility for your research

Submit your manuscript at www.biomedcentral.com/submit
Biomed Central 